\section{Lucky Osaretin Odia, ${ }^{1}$}

University of Benin, Faculty of Social Sciences,

Department of Sociology and Anthropology,

Benin City, Edo State, Nigeria
SCIENTIFIC REVIEW ARTICLE

doi:10.5937/ekonomika1802069O

Received: January, 03, 2018

Accepted: March, 21, 2018

\title{
SERVICE DELIVERY: A MITIGATION MEASURE TO RESOLVING INTER-COMMUNAL CLEAVAGES
}

\begin{abstract}
The desire to eliminating inequality in society is a better measure in assessing leadership pattern as being functional or failed in relation to service delivery capability. Quality service delivery - educational, access road, potable/piped water supply, health facilities, and the likes - are mitigation measures in redressing intra and inter-communal cleavages while the absence of quality/passive service would continually aggravate tension/unrest among people who hitherto lived together as brothers for decades. The paper examined the role of genuine service delivery measure in mitigating inter and intra-communal cleavages exploring Nigeria's/ other third world nations experience. This paper is of the view that when you have a set of jokers as leaders and jokers as commentators on public discourse in society, the situation of the ordinary man in the street becomes much more precarious and more precarious where those entrusted with public funds/ responsibilities celebrate failure and mindlessness rather than remorse openly for their ineptitude. The people must learn to understand the intrigues of the politicians whose stock in trade is trading on the interest and future of the people they claim to represent. This reorientation call becomes more imperative in view of the growing distance between the group known as the led and leaders in our society.
\end{abstract}

Key words: Capabilities, Conflict, Power, Rivalry, Political Leadership

JEL classification: $R 11, R 12, P 48$.

\section{ПРУЖАЊЕ УСЛУГЕ: МЕРЕ ЗА РЕШАВАЫЕ ИНТЕР КОМУНАЛНОГ ЈАЗА}

\begin{abstract}
Апстракта
Жеља да се елиминише неједнакост у друштву је боља мера у проиени лидерског образиа као функиионалног или неуспешног у односу на способност/ могућност пружања услуга. Квалитетно пружање услуга (едукативне улоге, изградња приступних саобраћајница, снабдевање водом (изградња водовода), канализација, здравствене услуге и слично) су мере ублажавања (или решавања) интра и интер комуналног јаза, док одсуство квалитетне/ пасивне услуге континуирано погоршава тензије /немире међу људима који су живели као браћа. У раду је испитивана улога стварне мере пружања услуга
\end{abstract}

${ }^{1}$ odialucko@yahoo.com 
у ублажавању интер и интра-комуналног јаза у Нигерији и другим земљама трећег света.

Кључне речи: способности, конфликт, моћ, надметање, политичко лидерство.

\section{Introduction}

The view of experts and world leaders including President Barack Obama of the United States of America is that for a nation to be great and progressive, what it needs is not a strong man as a leader, but strong and functional institutions (Songwe, 2015). These institutions regulate and direct the affairs of the people as well as meeting the basic needs of the people through adequate service delivery. Adequacy or lack of service delivery is a determining factor as to whether a government desires the people's fulfillment which is a prelude to peace and tranquility as well as propeller of society's progress.

Third World Nation's experience today, relates to how politicians in the name of 'leaders' perceive community progress. The urban elite politicians make effort in holding on to the control of the local community's affaires with the pretence that they are pursuing community's interest, whereas they are leveraging on the community's prospects for status sustenance and enhancement. In advancing self interest through self aggrandizement, they emphasize their passive effort towards community development as against actually meeting the community needs or advancing the course of the community (Omofonmwan \& Odia, 2009).

In the absence of genuine development effort from the three tiers of government, different segments of community members innovatively in their own way come up with programmes, with the pretence of addressing community needs. These local innovations include formation of groups such as community youth associations, community development associations, landlords associations and the likes, with the purpose of engaging in levy collections from fellow community members and those having one form of transaction or the other to carry out in the community. The usual outcome of such innovations have been self enrichment, tussle for group leadership, intra group/inter group cleavages, violent/wanton destructions of lives and properties and so on. Hove, Ngwerume and Muchemwa, (2013) observed that service delivery must also incorporate infrastructure for transport, communication, and other essential utilities including the supply of electricity, water, and the disposal of sewage and other waste. On the social side, municipalities need to provide facilities for various levels of education and health services (Hove, Ngwerume \& Muchemwa, 2013). While some services such as telecommunications and utilities may be more efficiently provided by private enterprises, social services in particular will continue to be the responsibility of public authorities.

This paper examines the pattern of leadership predominantly found in most Third World Nations and how such leadership have overtime retrogress communities and ethnic groups through their action and inaction and expected measures in addressing the very ugly trend. 


\section{Service Delivery}

Public office holders who have failed in the discharge of their assigned responsibilities and expectations usually make effort to seclude themselves from the people they represent. And sometimes make effort to convince the few that have access to them, that their inability to deliver in terms of service delivery is not ordinary and do ascribe same to possible supernatural causes. The people most times, run into more dilemma when those who during electioneering campaign claimed having solution to all the challenges in their domain suddenly turned complainers. They also ascribe their failure or inability to deliver to previous leaders, especially those in other political platforms. Others among these representatives in addition to excuses embark on what is referred to as secondary degree of cajoling with a perpetuation of falsehood that all would be well and punishment for those who make effort to say the truth.

Good governance is an essential ingredient needed in the course of service delivery to the people in any society and veritable tool in assuaging conflicts among disputants before same degenerates into crisis situation (Best, 2012).

Manda and Mwakudo (2013) while reviewing recent trends and outcomes in the education and health sectors in Sub-Saharan Africa, with a focus on the quality in service provision, observed low and ineffective spending on service delivery sectors as a symptom of the underlying institutional environment decay. The authors further argues that a microeconomic approach that explicitly takes political and bureaucratic incentives and constraints into account provides a fruitful, and complementary, way forward. Their findings reveal that innovations in the measurement of performance and ability in education and health open up ways to influence the political economic equilibrium (Manda \& Mwakudo, 2013).

Ayinde and Miah noted that countries that have been able to efficiently allocate their scarce resources to the productivity efforts by virtue of their effective institutions are states with developed economies (Ayinde \& Miah, 2008). In contrast, countries with weak institutions that encourage extensive unproductive rent seeking and other unethical behavior end up with economic backwardness. Drawing evidence from the developmental experiences of Bangladesh and Nigeria (and the failure therein), the authors seeks to juxtapose theory with reality with a view to contributing to the development discourse. They found that institutional constraints are the major impediments to sustained economic progress in both countries. Karl Mannheim (1952) cited in Kobiowu (2006) aimed at education as tool for the elimination of hostilities and conflicts, through shared experience and communal living. Sheer effort must be made possible to erase tribal problems, conflicts and sentiments from our education/political system (Odia, 2013).

Leading among the nation's dilemma is corruption. Suffice to say, that the meaning of corruption is evolving as well as taking different dimensions. One of the included attributes is the use of excessively acquired wealth through corrupt practices to acquire higher political power at all cost and subsequently leveraging on that influence to probe and fight/persecute political opponents who may not even be corrupt in the true sense of it. This they do with the conviction that such action will portray them as good and responsible in the eyes of the general public.

Among the determinants of a nation's productivity capacity prospects include; how developed are the educational system, amount of skills and competences in relation 
to its population, amount of recognition given to the nation's professionals, quality of leadership/service delivery profile and encouragement/acceptance of local inventions and so on.

Properly educated and informed leaders will adhere to the tenets of human capital development theory, by ensuring that inequality, poverty, ignorance, disease, lack of capacity and so on are fought with vigor through education, socio-economic empowerment and functional leadership. Leaders who fails in this direction, usually do so with the intention that the more uninformed and underpowered people especially youths in society, the more people that would be available for use in advancing their inordinate ambitions - seeking and capturing power at all cost as well as attacks on perceived opponents - in neglect of productivity pursuit. This trend, if not addressed urgently would entrench a system that breeds legions of unproductive population leading to unproductive nation due to socio-economic incapacitation of the people by unproductive leaders (Baker, 2009; Nnaji, 2015).

Rural entrepreneurs are people with the understanding of the entrepreneurial dynamics in the rural areas which are mainly trading and processing of agricultural produce requiring the needed support and empowerment from government and development stakeholders in properly harnessing their potentials. Stemming from the incidences of failure in governance which hampers service delivery quest, deprived and innocent citizens and security operatives eventually become victims of the action and inaction of deceitful political leaders.

One consequence of escalating urban poverty is the growing number of street children in African cities. While some of these children have homes and families but survive by begging or casual work, many have been deserted or orphaned and have no alternative but to live on the street. Their survival is tremendously precarious, and, without schooling, they have little hope for any meaningful future and are extraordinarily vulnerable to abuse. For many, prostitution and crime are the only means to survive. In post-conflict countries street children are one of the most visible legacies of armed conflict. In particular, child soldiers, who are often alienated, traumatized and habituated into violence, present a daunting challenge (Rakisits, 2008).

The gap between demand and supply is widening in many cities. Existing facilities are poorly maintained, and investments in expanded service delivery are constrained by lack of financing. As a result, traffic congestion, inadequate public transport, crumbling roads, intermittent and unreliable electricity, poor telecommunications and insufficient water supply are becoming the norm rather than the exception, even in affluent areas of cities. In some cities, bribery has become commonplace as a means to forestall arbitrary interruption of utility services (Newsday , 2012).

In general, lack of adequate infrastructure ranks high among the most basic impediments to economic growth in most Sub-Saharan African countries (United Nations, 2004). In an increasingly scientific and knowledge-based world, businesses in SubSaharan Africa are disadvantaged by the fact that, with the exception of South Africa, the region has the world's least developed information and communications infrastructure. However, poor infrastructure in cities affects the economic performance of the private sector as well as the living conditions of citizens. The increase of slums means that hundreds of thousands of people live in appalling housing structures and without facilities like sewerage, electricity, water or paved roads (World Bank, 2005). For example, in 
Harare the influx of people exerted mounting pressure on the Harare Municipality for the supply of amenities such as housing, clinics, transport, health facilities and water and sewage infrastructure. The shortage of housing compelled impoverished urban arrivals to construct illegal shelters leading to increasing shanty dwellings in the city (Colquhoun, 1993). Thus, Zimbabwe's capital city has joined the growing list of cities and 'mega cities' of the global south, which are confronted by an ever-growing crisis of deficient provision of basic services (Musemwa 2010). Emblematic of these challenges are other cities such as Lagos, Nairobi, Kumasi, Maputo and Luanda, amongst others. The continuance of rural habits by large numbers of people unaccustomed to living in an urban environment, together with lack of maintenance, has further contributed to the decay of physical infrastructure in cities. This has undermined overall human security and the attainment of sustainable development (Hove, Ngwerume \& Muchemwa, 2013).

High rates of unemployment and limited economic opportunities have created a potentially explosive social problem in many African cities, especially given the particularly high levels of youth unemployment (Eguavoen, 2010). As a consequence, generating economic growth and employment have become development imperatives for urban areas throughout the continent. To accomplish this will require significant expansion of the formal private sector, which remains underdeveloped in most African countries. It will also require the encouragement and facilitation of much higher levels of private investment. In the long run, countries cannot compete internationally on the basis of a largely informal economy.

\section{Inter-communal Cleavages}

It could be thus said that the unabating rivalry and tension between the Itsekiris on the one hand, and the Ijaws and Urhobos on the other, which seem to dominate the politics of the region over the years, has a lot to do with the imposition of British colonial rule. It fostered antagonistic relationship between the three ethnic groups as each tried to undo the other in the process of adjusting to the new political and social order in which they found themselves. The decision to group these hitherto interdependent ethnic groups together under Warri province, in which the Isekiris occupied a position of dominance, was bound to invite the adverse reaction of the other two ethnic groups (Imobighe, 2008).

In specific terms, the rapid and relatively extreme breakdown in the structure of social system of a number of Africa States associated with domestic insecurity results directly from an extraordinary complex mix of "underdevelopment and poverty and distributive justice" (Ayoob, 1986). The structural roots of these malignant social conditions (to use Morton Deutsch's category) resides invariably in three major contradictions in the social system of African societies (Alavi, 1983; Sandbrook, 1985). One such contradiction relates to the history and nature of state formation in Africa as compared for instance, to its counterpart in Europe. Another contradiction derives from the "pattern of elite recruitment and regime establishment and maintenance". The implication for peace and security of these factors can be seen in the crisis of regime legitimacy which befell many African Countries in the last three decades. The dynamics of this crisis are primarily anchored to a third contradiction: relations of exploitation, domestic class structures, prostrate external dependence and the nature of the client post 
-colonial states that these class structures have developed, also operate to intensify the crisis (Onimode, 1988; Bassey, 2008).

As C.R. Mitchell puts it: conflict is inevitable because it can originate in individual and group reactions to situation of scarce resources; to division of function within society; and to differentiation of power and resultant competition for limited supplies of goods, status, valued roles and power-as-an-end itself (Bassey, 2008).

Susan Randell and Herman Strasser common to all conflict theoretical approaches is that they explain change in terms of antagonism or tension-producing elements that are inherent in social systems. The causes of such conflicts of the social structure which, on the one hand, are related to the establishment and sanctioning of social norms and, on the other hand, to the control and allocation of scarce resources such as income, property, influence and authority (Bassey, 2008).

As Morton Deustch trenchantly notes: if one wants to create the conditions for a destructive process of conflict resolution, one would introduce into the conflict the typical characteristics and effects of a competitive process: poor communication, coercive tactics; suspicion; the perception of basic difference in values; an orientation to increasing power differences; challenges to the legitimacy of the parties and so forth. On the other hand, if one wants to create the conditions for a constructive process of conflict resolution, one would introduce into the conflict the typical effects of a co-operative process: good communication; in the perception of similarity in beliefs and values; full acceptance of one another's legitimacy; problem centred negotiation; mutual trust and confidence; information-sharing and so forth (Bassey, 2008).

At the bottom of the Jos conflict in Nigeria is the competition for political control as well as the issue of indigeneship. The competition and conflict springs from who is an indigene and who is not, and the rights and privileges derivable from an indigene. Thus, indigeneship is not a mere status but a status that begets specific political, economic and psychological benefits (Best, 2007, p.5,). Ali and Imai study reveals that crises are associated with growth collapse in Africa. The authors added that in contrast, openness is found to be beneficial to growth and mitigate the adverse effects of crises (Ali \& Imai, 2015).

Politicians in the course of seeking political office, adopts all sorts of gimmicks to cajoling the people and sometimes resort to the use of incendiary/odious statements while undermining the possible consequences of such statements (Ofuani,2012; Nnaji,2015).

\section{Institutions and Service Delivery}

The quality of services delivered is an important determinant of people's wellbeing for a given bundle of resources. Resources are critical to the delivery of services to clients. But resources are just only one, and sometimes a small component, of the performance factors that impact on the quality of service provision. Recent evidence shows that even when resources are allocated for provision of services, a large portion of the resources might not reach the intended clients. In some cases, services may not even be provided because frontline providers do not show up to work, resulting in poor delivery of services. The implication is that availability of resources does not guarantee that intended beneficiaries do in fact receive the benefits from the resources allocated 
(Manda \& Mwakudo, 2013). The authors, where of the view that this situation explains the often observed result of weak relationship between for example, health expenditures and health outcomes in developing countries. In fact there are cases for which increased expenditures have been associated with decrease in health and other indicators of wellbeing. Such outcomes reflect weaknesses in the internal efficiency of the delivery mechanisms. Simply, budgetary allocation for a particular service may be only weakly related to what is delivered to clients. Among the factors orchestrating poor productivity in Nigeria according to Odia include; influence of poverty precipitating inability to meet the cost of schooling, the growing notion base on some degree of realities on ground, that life goals such as power/wealth could be acquired through any possible means with or without education (Odia, 2013). The author added that the quest for productivity might remain precarious for sometime should the existing scenario where majority of those graduating from the nation's tertiary institutions/inventors are continually allowed to roam the streets while those with little or no skill/competence heads/direct the affairs in the various sectors noting that the functioning capability of institutions cannot be separated from the quality and competences of societal leadership.

The quality of service delivery is dependent on resource constraints--both financial and human. Provision of services requires tangible financial resources, and, given that many developing countries face severe resource constraints, quality of provision is likely to be poorer in these countries relative to more economically advanced countries. This is because the technology of delivery and the quality of service infrastructure is likely to vary across countries with different levels of income. Likewise, human resources in terms of knowhow and organizational capacity are an important determinant of service delivery. To the extent that these resources are relatively scarce in poor countries, then service delivery can also be expected to be considerably poorer (Manda \& Mwakudo, 2013). The authors added that while both human and financial resources are crucial determinants of service delivery, availability of resources does not guarantee efficient delivery. Institutions and institutional arrangements appear to be very important determinants of service delivery. The quality of institutions for service delivery can, therefore, be evaluated on the degree to which they promote accountability within the service delivery chain. Thus, linking institutions to service delivery requires a clear understanding of the factors that impact on service delivery and how those factors vary across institutions (Nkwe, 2012).

The civil service has prominent roles to play in service delivery. The development achieved in many countries of the world has been due to the ability of their civil service to effectively translate the policies of their political leaders into concrete services (Faseluka, 2015).

A properly functioning public service is indispensable to good governance, institutional capacity building, and private sector development. SERVICOM policy must be sustained, alongside other related initiatives, until Nigerian public life is truly transformed (Ogunrin \& Erhijakpor, 2009).

Agunyal added that effective dispensation of these responsibilities depends largely on the capability, knowledge and expertise of the existing institutional actors and structure (Agunyal, 2015). Nevertheless, service delivery at the local level of governance in Nigeria is highly deficient because of the low capacity of staff. The added that studies have shown that there is a close link between staff development, capacity building and 
efficient service delivery. Thus, the need for enhanced training and retraining through further studies, seminars, conferences, workshops, symposiums, and so on (Michael, 2009).

\section{Theoretical Framework}

The theories found suitable for the analysis of service delivery: a mitigation measure to resolving inter-communal cleavages is the system theory of good governance. Good governance relies on instruments of governance that nurtures and strategically utilizes the self-governing potential of civil society under the strategic supervision of public authorities, seen in such diverse areas as employment policy, police power and crime prevention, health policy and biopolitics, employment policy, educational policy, accounting practices etc. (Bang \& Esmark, 2013). The authors add that to avoid initial confusion: the notion of good governance does not refer to a scientific theory of governance or governance as a research program. Good governance refers to an empirically observable politico-administrative way of making public policy-making, reforming and organizing. There are countless applications of the concept of governance, as has been noted by several observers (Rhodes \& Jessop, 2015), leading others to question the theoretical value of the concept (Bang \& Esmark, 2013). Moreover, the many applications of the governance concept oscillate between scientific and practical applications, between research programs and policies, between observation and the object of observation itself (Jessop 2012, Meuleman 2008). Indeed, governance theory is often part and parcel of the strategy of good governance rather than an external observation (Easton \& Dennis, 1973; Easton, 1990).

Good governance involves particular stances and notions about the organizational reform of the public sector. As such, good governance covers three basic politicoadministrative domains: public governance, policy and organization. Good governance strategies are diverse, but they share a common language of problematization, including possible solutions. On this level then, good governance amounts to a strategy of mobilization. This strategy involves, on the one hand, a call for flexible integration of various forms of knowledge, expertise and resources to tackle complex or 'wicked' policy problems and provide sufficient innovation and ownership of solutions, and, on the other hand, an appropriation of democratic vocabulary in terms of inclusion, accountability and participation (Bang \& Esmark, 2013).

For one, good governance is not restricted to the political domain in the narrow sense. Although the authors focus on good governance as politico-administrative strategy, i.e. as a question of public governance, the majority of its instruments and techniques are an emulation of business, science, family etc. and their various rationalities. Second, although there are clearly semantics of good governance centered around concepts such as 'competition', 'performance', 'quality' and 'innovation', this semantic complex is neither coherent in itself, nor is it necessarily comprehensive in relation to good governance on the levels of strategy and techniques. Attractive as the idea may seem, strategies and techniques do not converge towards a common reference point on the level of rationalities. And vice versa: we cannot think of the strategies as being simply derived from rationalities and of techniques as the implementation of strategies. Rather, 
good governance emerges only as the partial coupling of certain techniques, strategies and rationalities (Bang \& Esmark, 2013).

Essentially, a function system is nothing but the innumerable past and present communicative events and processes relying on a particular symbolically generalized medium, aided by other communication structures such technological mediums of diffusion, specialized discourse and language etc. Symbolically generalized mediums include power in the case of the political system (Luhmann 1997; 2000c, pp.18), the medium of law in the legal system (2004, pp. 173), money in the economic system (1988, pp. 213), truth in the scientific system (1990, pp. 308), love in the case of the family (1986, pp.18) etc. As Luhmann states, 'the most successful and relevant communication in current society is premised on such mediums, and consequently the formation of social systems are directed towards the corresponding functions' (Luhmann, 1984, p. 222). The combined dynamic of increasing territorial inclusivity and communicative exclusivity of function systems adds up to a completely differentiated world society without recourse to any meta-principle capable of ensuring integration between or beyond the communicative rationality of function systems and their constitutive mediums (Easton, 1965).

It is an established fact that good governance precipitate effective and genuine service delivery in any society through informed and committed leadership and strong institutions thereby mitigating incidences emanating from ill feelings resulting from lacks and deprivations. Those at the helm of affairs must henceforth act differently with the view of jettisoning the already mounted tension due to a long time of abandonment of the people and their plight by leaders. Preceding steps leading to the desired change are well captured in the 12 principles for good governance as enunciated by Council of Europe (2014) include i. Fair conduct of elections, Representation and participation ii., Responsiveness, iii., Efficiency and Effectiveness iv., Openness and Transparency v., Rule of law vi., Ethnical conduct vii., competence and capacity viii., Innovation and openness to change ix., Sustainability and long term orientation x., Sound financial management xi., Human rights, cultural diversity and social cohesion xii., Accountability.

The summation of Barack Obama, succinctly espoused in clear and practical terms, the desired strategies needed in assuaging the socio-economic debilities occasioned by poor/lack of service delivery to the people with his remarks: "In the $21^{\text {st }}$ century, capable, reliable and transparent institutions are the key to success-strong parliaments; honest police force; independent judges.... an independent press; a vibrant private sector; a virile civil society. Those are the things that give life to democracy, because that is what matters in people's everyday lives" (Woodward, 2009; Baker,2009).

\section{Methodology}

The study focused on service delivery, as a mitigation measure to resolving inter-communal cleavages. A very volatile region in one of the six geopolitical zones (the Niger- Delta region) in Nigeria was studied. The Niger-Delta region of Nigeria, consist of nine states: Ondo, Edo, Delta, Bayelsa, Rivers, Cross Rivers, Akwa Ibom, Imo and Abia state. Four communities were sampled from each of the nine states and ten respondents were administered questionnaires in each community. The respondents in each community consist of five head of household, two women and three youth leaders. 
A total of 360 respondents were administered questionnaires in the study area. A five (5) point Likert Scale Format questionnaire with some added open end questions were used in eliciting the desired responses. In-depth interviews (IDI) and focus group discussions (FGD) were also conducted. Phi correlation coefficient statistical tool was used.

\section{Findings}

Proposition testing

Service delivery does not assuage inter communal cleavages

1. By service delivery, is referring to capability of leaders in government in providing communities with basic needs.

2. By assuaging inter communal cleavages, is referring to measures put in place to remedy or preventing conflict among communities and their neighbours.

3. By perception, is referring to "Yes and No".

To test the proposition, phi - correlation coefficient is used.

(see Table 1)

(see Table 2)

(see Table 3)

Phi - correlation coefficient is used.

Phi correlation

Denoted by $\varnothing$ or $\varnothing$

The formula for $\varnothing=$

$$
\begin{aligned}
& \varnothing=\frac{a d-b c}{\sqrt{(a+b)(c+d)(a+c)}(b+d)} \\
& \varnothing=\frac{440(250)-280(473)}{\sqrt{(720)(723)(913)(530)}} \\
& \varnothing=\frac{110000-132440}{\sqrt{(520560)(483890)}} \\
& \varnothing=\frac{-22440}{501890} \\
& \emptyset=\frac{-22440}{501890} \\
& r \varnothing=-0.045 \\
& \mathrm{r}^{2} \varnothing
\end{aligned}
$$




\section{Interpretation}

From the phi correlation result which shows that $\varnothing=0.045$, implies that the relationship between service delivery effort as a mitigation measure in resolving intercommunal cleavages is very very low in the study area.

Therefore, the study would reject the propositions which say that service delivery does not assuage inter-communal cleavages and accept the propositions that service delivery is a mitigation measure in resolving inter-communal cleavages.

Furthermore, based on these findings, the study can conclude that the provision of social services to communities by government, donor agencies, corporate organizations etc are very low in the study area. Therefore, the study suggests that effort should be made by government, political office holders and other stakeholders to provide adequate social services (improved infrastructure/facilities, skills and financial empowerment and increased access to opportunities, etc) to dwellers in the study area as against the present trend in which the people are served more with falsehoods and reasons while they (political office holders) have failed to deliver.

\section{Discussion}

The cause of absence of basic amenities/facilities in some communities are sometimes attributed to the influence of neighbouring communities who they believe would have physically or spiritually denied them of their wants. A community leader was observed to have said in one of the author's field survey that the low patronage of their community market, the dilapidated/poorly staffed secondary school and host of other basic essentials lacking in the community are believed to have be orchestrated by one of their neighbouring communities. He supported his claim with evidence of the fact that someone who recently confessed in the community of having the patronage of their facilities transferred/sold to the other community spiritually. Empirically speaking, teachers for instance are not employed in the spiritual realm to teach in schools neither are basic infrastructures especially those whose funds have been diverted or stolen after same being budgeted for and funds released. Overtime those in leadership positions concoct reasons why roads are not fixed, schools not having needed infrastructure/facilities, absence of piped potable water, quality/accessible health facilities, poor/inadequate housing, security, transportation, marketing facilities/incentives, communication, and so on. In addition, political leaders in government sometimes spend more money on advertorial/commissioning of projects when eventually executed. This usually creates a situation of ill feelings, deprivation, lacks, sense of exclusion/rejection among the people and the resultant effects of innate and overt struggle for access to any the services. These were the submissions of respondents and discussants in the study's in-depth interview and focus group discussion.

A community leader asserted that governance at the local level is not difficult for a leader who want to deliver and question the difficulty in earth road grading/ maintenance, primary health care facilities, but some of them would prefer to steal and share available public funds among cohorts and their election sponsors even when they openly advocates absence of "godfathers". According to Michael (2009) it is noted among others that electoral fraud is a consequence of low level of development 
of productive forces, which in itself, is reinforced by the existence of insipient social atomization; as well as the persistence of mangled and distorted social relations of production.

The service delivery challenges permeate the various ties of governance in the country. The government cannot harness the potentials of rural dwellers, making them more productive to earn good income and improve the savings and investment capacity. These, coupled with a lack/poor services, ruralite are compelled to migrate in search of greener land, with or without a prerequisite competence to function properly and to earn good income that would enable them lead lives of dignity and fulfillment. The few urban centres' dwellers on the other hand, also battle to access the limited services available. A society desirous of genuine progress, pursue the issue of capacity and competences of citizens in carrying out their economic activities. With the conviction that the degree of proficiency in carrying out economic activities is a prelude to the level of productivity and level of income which tax is predicated upon (Songwe, 2015) .

\section{Conclusion}

Government must address issues dispassionately and pragmatically by ensuring fairness, equity and justice in service delivery, participation and representations in governance. Government must abhor all forms of sectionalization in political, economic and social service delivery which do precipitate bigotry in form of religious and ethnic cleavages. In addition to these, is the scenario where some privileged and opportunistic few use religion and primordial sentiments in sustaining their selfish elitist role in society (through odious and incendiary statements) at the very detriment of the majority innocent and deprived people desirous of services and not sensationalism, gimmicks or innovations geared towards seat tight in office/ sponsorship of cohorts to succeed them.

This paper holds that enabling laws empowering the communities to seek redress or compel political office holders, to meet their constitutional and basic needs, should be put in place and enforced to the letter as well as enforcing laws that would hold political office holders/public servants accountable for their actions and inactions while in pursuit of their inordinate ambitions. This way, Third World communities would begin to heave a sigh of relief and build a high sense of belonging as well as develop the culture of tolerance and accommodation for all while eschewing all forms of bitterness, prejudices and stereotypes against any group. As this remain one sure way of ensuring harmonious living, collective/communal goal attainment and national progress.

\section{References}

Agunyal, S.C. (2015). Manpower development, capacity building and service delivery in Ife- East Local Government Area, Osun State. Nigeria. Journal of Public Adm. Policy Res, 7 (1):1-14.

Alavi, H. \& Shanin (1983). Sociology of Developing Societies. London: Macmillan. 
Alexander, James. 2009. Vilfredo Pareto: The Karl Marx of Fascism part 11: Foxes and Lions.www.toqonline.com/blog/vilfredo.par..retrieved on 12/11/2015.

Ali, A., \& Imai, K. S. (2015). Crises, Economic Integration and Growth Collapses in African Countries. Journal of African Economies, 24 (4):471-501.

Ayinde, A. F., \& Miah, Dulal Md. (2008). Economic Backwardness in Nigeria and Bangladesh: An Institutional Analysis. Nigerian Journal of International Affairs, 34 (2): 29-48.

Ayoob, M. (1983). Security in the Third World: The Worm about to Turn? International Affairs, 60:1.

Baker, P. (2009). Obama Delivers Call for Change to a Rapt Africa. The New York Times, July 11.www.nytimes.com/../12prexy.html.

Baker, P. (2015). Nobody, Should Be President for Life, Obama Tells Africa. The New York Times, $28^{\text {th }}$ July.www.nytimes.com/2015/07/29/world/af

Bassey, C. O. (2008). Framework for The Conflict Transformation Project. In T.A. Imobighe, C. O. Bassey \& J. B. Asuni (Eds.), Conflict and Instability in the Niger Delta: The Warri Case. AAPW, Ibadan: Spectrum Books Limited.

Best, S. G. (2007). Conflict and Peace Building in Plateau State, Nigeria. Ibadan: Spectrum Books Limited.

Best, G. S. (2012). Introduction to Peace and Conflict Studies in West Africa. Ibadan: Spectrum Books Ltd.

Bang, H., \& Esmark, A. (2013). A systems theory of Good Governance. Paper prepared for ICPP, Grenoble 2013. Panel 45/session 1.

Castells, M. (2006). The network society: From knowledge to policy. In M. Castells \& G. Cardoso (Eds.), Societies in transition to the network society (pp. 3-23). Baltimore: John Hopkins University Press.

Colquhoun, S. (1993). Present problems facing the Harare City Council. In L. M. Zinyama, Tevera D.S \& Cumming S. D. (Eds.), Harare: The growth and problems of the city. Harare: University of Zimbabwe Publications.

Council of Europe 2014. The 12 principles for good governance at local level, with tools for implementation.www.coe.int $>$ council of Europe $>$ Democracy $>$ Good governance.

Easton, D. (1965). A systems analysis of political life. Chicago: University of Chicago Press.

Easton, D. (1990). The analysis of political structure. N.Y.: Routledge.

Easton, D. \& Dennis, J. (1973). A political theory of political socialization. In J. Dennis (Ed.), Socialization to politics (pp. 32-55). New York: John Wiley \& Sons.

Eguavoen, I. (2010). Lawbreakers and livelihoods makers: Youth specific poverty and ambiguous livelihood strategies in Africa. Vulnerable Children and Youth Studies: An International Interdisciplinary Journal for Research, Policy and Care, 5(3): 268-273.

Faseluka, O.P. (2015). Civil service administration and effective service delivery for development. The Guardian, 11 $1^{\text {th }}$ March, 2015.www.m.guardia.ng/ features.22/8/2016. 
Hafner, P. \& Krstić, M. (2011). Theory of rational choice in the analysis of criminal behavior, Ekonomika - Journal of Economic Theory and Practice and Social Issues, 57 (1): 37-47.

Hove, M., Ngwerume, E.T. \& Muchemwa, C. (2013). The Urban Crisis in SubSaharan Africa: A Threat to Human Security and Sustainable Development. Stability: International Journal of Security and Development, 2(1): 7.

Imobighe, T.A. (2008). Warri Crisis in Historical and Contemporary Perspectives. In T.A. Imobighe, C. O. Bassey and J. B. Asuni (Eds.), Conflict and Instability in the Niger Delta: The Warri Case. AAPW, Ibadan: Spectrum Books Limited.

Jessop, B. (1998). The Rise of governance and the risk of failure. International Social Science Journal, 50 (15): 29-45 .

Jessop, B. (2002). The Future of the Capitalist State. Oxford: Polity Press.

Jessop, B. (2003). Governance and meta-governance: on reflexivity, requisite variety and requisite irony. In H. Bang, (Ed.). Governance as social and political communication (pp. 101-117). Manchester: Manchester University Press.

Kobiowu, S.V. (2006). Sociology of Education; School and Society. In K.A. Ogunbameru \& W.R. Rotimi (Eds.), Man and His Social Environment A textbook of Sociology. Ibadan: Spectrum Books Ltd.

Krstić, B., \& Krsstić, M. (2015). Models of Irrational Behaviour of household and firm. Ekonomika - Journal of Economic Theory and Practice and Social Issues, 61 (4): 26-34.

Luhmann, N. (1997). Die Gesellschaft der Gesellschaft. Frankfurt am Main: Suhrkamp.

Manda, D. k. \& Mwakudo, S. (2013). Institutions and Service Delivery in Africa: An Overview. Journal of African Economies, 22 (2): 4-15.

Michael, A. O. (2009). The State, Electoral Fraud and illusion of Participatory Democracy in Africa: Lessons from the 2007 General Election in Nigeria. Nigerian Journal of International Affairs, 35 (1):61-77.

Musemwa, M. (2010). From 'Sunshine City' to a Landscape of Disaster: The Politics of Water, Sanitation and Diseases in Harare, Zimbabwe, 1980-2009. Journal of Developing Societies, 26(2): 165-206.

Nkwe, N. (2012). E-Governace: Challenges and Opportunities. In Botswana. Int. J. of Humanities and Social Sciences, 2 (17).

Nnaji, C. (2015) Reducing Cost of Governance (Sunrise, channels television, 20/11/2015, 9am).

Obama, B. (2015). President Obama's speech to the United Nations General Assembly 2015. New York Times.

Odia, L. O. (2013). The Nigerian Educational System and its Implications for National Development. Nigerian Journal of Policy and Strategy. 18 (2): 80-107.

Ofuani, C. (2012) Strong institutions not strong men. Vanguard. 7/8/2012.www. vangaurdngr.com.19/8/2016.

Ogunrin, F.O. \& Erhijakpor, A.E.O. (2009). Service policy intervention: improving service quality in Nigerian public sector. Global Journal of Social Sciences, 8(1). 
Omofonmwan, S.I., \& Odia, L.O. (2009). Oil Exploitation and Conflict in the Niger Delta Region of Nigeria. International Journal of Human Ecology India, 26 (2): 99-105.

Onimode, B.A. (1988). Political Economy of African Crisis. London: Zed.

Rakisits, C. (2008). Child Soldiers in East of Democratic of Congo. Refugee Survey Quarterly, 27(4): 108-122.

Rashmi, Priya - Pareto's Circulation of Elite: Characteristics and Criticism. www. youngarticlelibrary.com.retrieved on 12/11/2015.

Perkins, J. (2006). Confessions of an economic hit man. Ebury Press: New Ed Edition. USA.

Sandbrook, R. (1985). The Politics of Africa's Economic Stagnation. Cambridge: Cambridge University Press.

Songwe, S. (2015). From strong men to strong institutions: n assessment of Africa's transition towards more political contestability. $4^{\text {th }}$ August.www.brookings.edu

United Nations (2004). World Urbanisation Prospects: The 2003 Revision. New York, NY: United Nations.

Woodward, P. (2009). Obama holds up Ghana as model democracy. July 12. The National. Friday, May 20, 2016.

World Bank (2002). World Development Report 2002: Building Institutions for Markets. Oxford: Oxford University Press.

World Bank (2005). Working Paper Series No. 97: The Urban Transition in SubSaharan Africa: Implications for Economic Growth in Africa Region. Washington, DC: World Bank. 